\title{
The potential of and limitations to marine population prognosis
}

\author{
W. Greve \\ Biologische Anstalt Helgoland; Notkestr. 31, D-22607 Hamburg, Germany
}

\begin{abstract}
Following the 19th century recognition and definition of basic ecological entities, functional analysis has been the highlight of this century. The synthesis of these findings enables ecological prognosis. The population as the basic functional unit has been repeatedly treated in the marine field, fisheries management approaches developed into multi-species population analysis. As in planktology, theoretical ecology, and classic biocoenotic research, the population interactions are of increasing scientific interest. A mathematical model is suggested that combines these extrinsic and intrinsic functional relationships in order to define the fit of the ecological niche to the environment, the decisive measure of the expected population success, and thus of the probable population development needed for prognostic purposes. It is discussed in how far the orientation towards the predictive power or - with respect to the "skill" of meteorological prognoses - the "ecological prognostic skill" improvement may serve as a means to choose the best investigative strategy.
\end{abstract}

\section{INTRODUCTION}

The 19th century was a period of great ecological definitions, some of which are related to the investigation of the German Bight. Ernst Haeckel coined the word 'ecology' in 1866, a year after visiting Helgoland, Victor Hensen coined the word 'plankton' in 1887, Karl Moebius coined the word 'biocoenosis' in 1877. Friedrich Heincke recognized population as the basic functional unit in ecology in 1878 , when he treated regional herring stocks.

Following this definition phase, but - as in Heincke's work - simultaneously, the analytical phase started with equally fascinating innovative findings. During the 20 th century, the functional analysis of ecological processes evolved and peaked after the introduction of computers made the complexity of ecological systems tractable. Names to be related with benchmark papers in this respect might be Lotka (1925), Volterra (1926), Ivlev (1944), von Bertanlanffy (1950), Ricker (1957), Strickland (1965), Steele (1974), Anderson \& Ursin (1977) and many others, especially groups of scientists, who were equally important for the functional analysis of ecological systems. Besides this direct functional analysis of ecosystems starting from conceptual models of the ecosystems, the physiological and ecophysiological analysis revealed powerful functional relationships, too (e.g. Banse, 1976; Peters, 1983; Valiella, 1984; Huntley \& Lopez, 1992).

If the analytical phase has reached a peak in the 20th century, the time should be ripe for the synthetic phase at the edge of the next decade, especially as ecology appears not to have the public recognition it deserves. Peters (1983) says: "Over the past two decades, 
eloquent spokesmen have sensitized public and politician to environmental degradation. However, when asked for practical advice, our directions were frequently little more than platitudes and aphorisms", and: "Much of modern ecology is scientifically weak and practically futile. Our theories are too frequently vague verbal statements, incapable of rigorous predictions and, therefore, not subject to rigorous tests."

At the same time, the management sciences have dealt with ecosystems, including marine ecosystems. "Water-quality management" (e.g. Koudstal, 1987) serves as a surrogate for more knowledgeable ecosytem handling. Fedra (1995, this conference) presented advanced computer software for the use of diverse expert knowledge for an integrated decision support-system.

\section{PRINCIPLES OF POPULATION PROGNOSTICS}

The demand for prognoses arises with fisheries management, with environmental management (especially the avoidance of possibly harmful plankton blooms such as Chrysochromulina polylepis or Phaeocystis globosa), with 'global change' anticipation of immigrating new species which could modify the biocoenotic (see Hedgpeth, 1977) regimes (e.g. Greve \& Reiners, 1991). All these cases are examples for the requirement of population prognoses.

Populations are defined as the representatives of a species in a certain space. Within this space the conditions are more or less advantageous for a population. The sum of all populations' requirements has been defined as the ecological niche (Elton, 1927), a multidimensional hyperspace (Hurlbert, 1981). The degree of fit of the ecological niche with the actual conditions would determine the expected population success (Fig. 1). Of course, linear relationships are rare in any dimension of the hyperspace. Satiation curves or thresholds will be much more realistic. Within the dimensions of the niche, a hierarchy of importance of the single relationship can be expected. Figure 1 displays this in levels of shading. In essence, Liebig's "law of the minimum". (Liebig, 1840) can be recognized as the first description of the ecological niche. Gillbricht (1969) already theorizes: "The total environment influences the development of a species or a population, but normally one factor only influences, de facto, the system at any moment." Though the minimal fit of parameters of the ecological niche could be a key-value the procedure to find out this from all the parameters encompassing the ecological niche will not be trivial, in any case it cannot be determined by inspiration but hopefully on the basis of a rational procedure such as Fedra's (1981) extraction of a simulation model from given time series using topdown Monte Carlo calculation routines, ending with a result comparable to Greve (1981), who worked on the same biocoenoses using a bottom-up approach.

A survey on the potential parameters of the ecological niche leads us to all analytical biosciences and the abiotic environmental parameters (Fig. 2). Though the proper ecological subjects represent the major part of the niche - hyperspace, general physiological information helps to narrow the space of the possible, understanding prognosis to be the attempt to define the probable within the possible (Peters, 1983). The space of the possible is not only limited by intrinsic factors e.g. the organism's physiology, telling us possibly about the potential invaders of the North Sea, coming from the Mediterranean and waiting in the English Channel for the winter temperatures to rise to their physiological requirements (Lüning, pers. comm.). It is also reduced by extrinsic factors e.g. climate, 


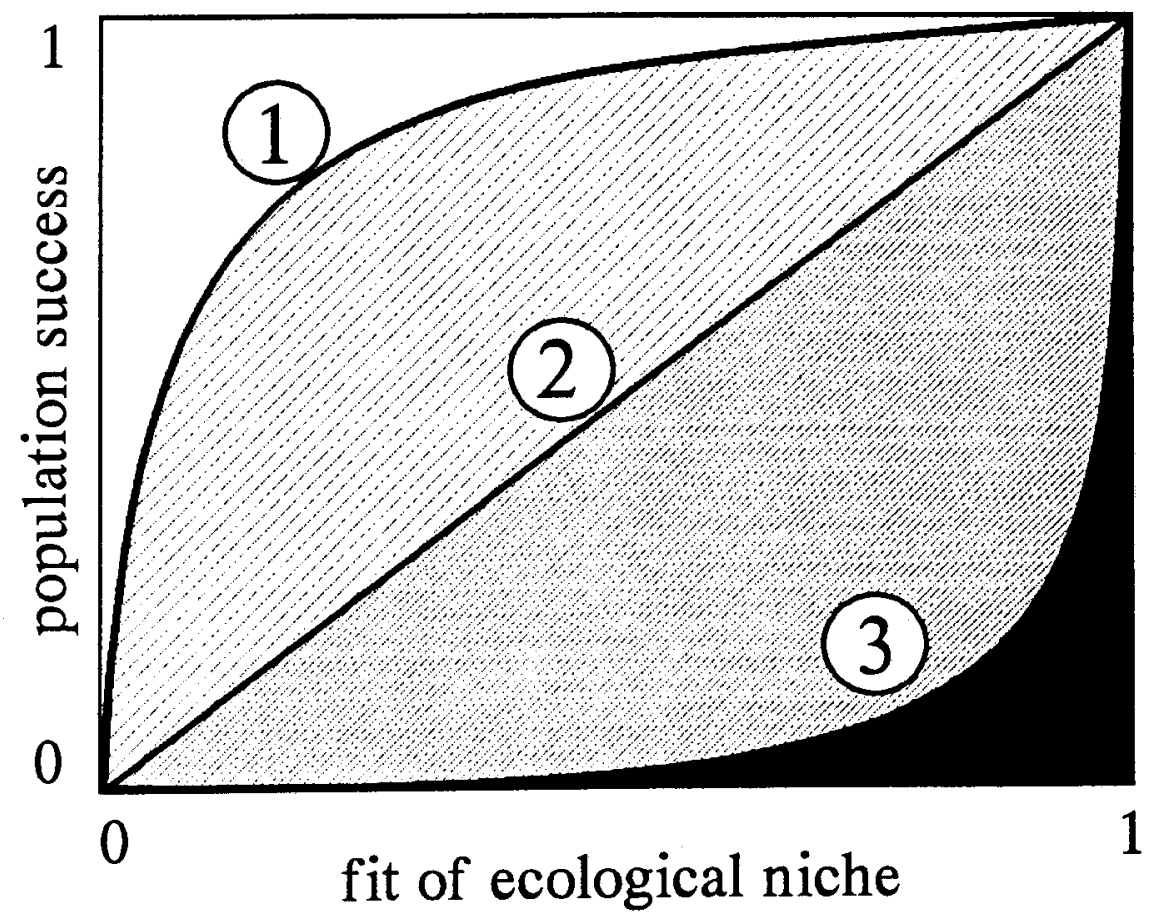

Fig. 1. Scheme of the influence of the 'fit' of the ecological niche on the population success. Arbitrary functional relationships assuming satiation (1), linear (2), threshold (3) functional relationships. (Resource-dependent processes either respond quickly to the presence of a resource and then stay at a maximal level reached, or linearly depend, in a dose-effect relationship, on the resource, or they require a certain quantity of the resource, before responding. All three types may be combined in

specific functional relationships.) The density of shading stands for the estimated relevance

currents and biocoenotic developments. These may function on the basis of population interaction from prey-predator systems, mutual-predation-based bifurcations, chaotic system behaviour, the cyclic destruction-renewal process of communities (Holling, 1986), the mosaic-pattern sequence (Remmert, 1991), autopoietic relationships (Dress et al., 1986) or anthropogenic environmental modification through e.g. fisheries or pollution. All these limit the range of the possible, and may determine the probable.

Any specialized biologist - whether production biologist, biocoenologist, population ecologist, physiologist or biostatistician - having a long record of events which were possible in the past, could predict some aspects of the possible and the probable. But none of this expertise will completely cover the predictive potential that already exists. Such knowledge-engineering requires another group of specialists.

Advanced computer software (Fedra, 1995) will be able to aggregate such expert knowledge, apply further numeric expertise (e.g. neural networks) within such expert systems, thereby further narrowing the band of the possible and the probable. During this process a comparison of the various results adding to the expertise will be possible, with respect to their contribution to the prediction.

Meteorology is the science with the greatest experience in prognostics. The science 


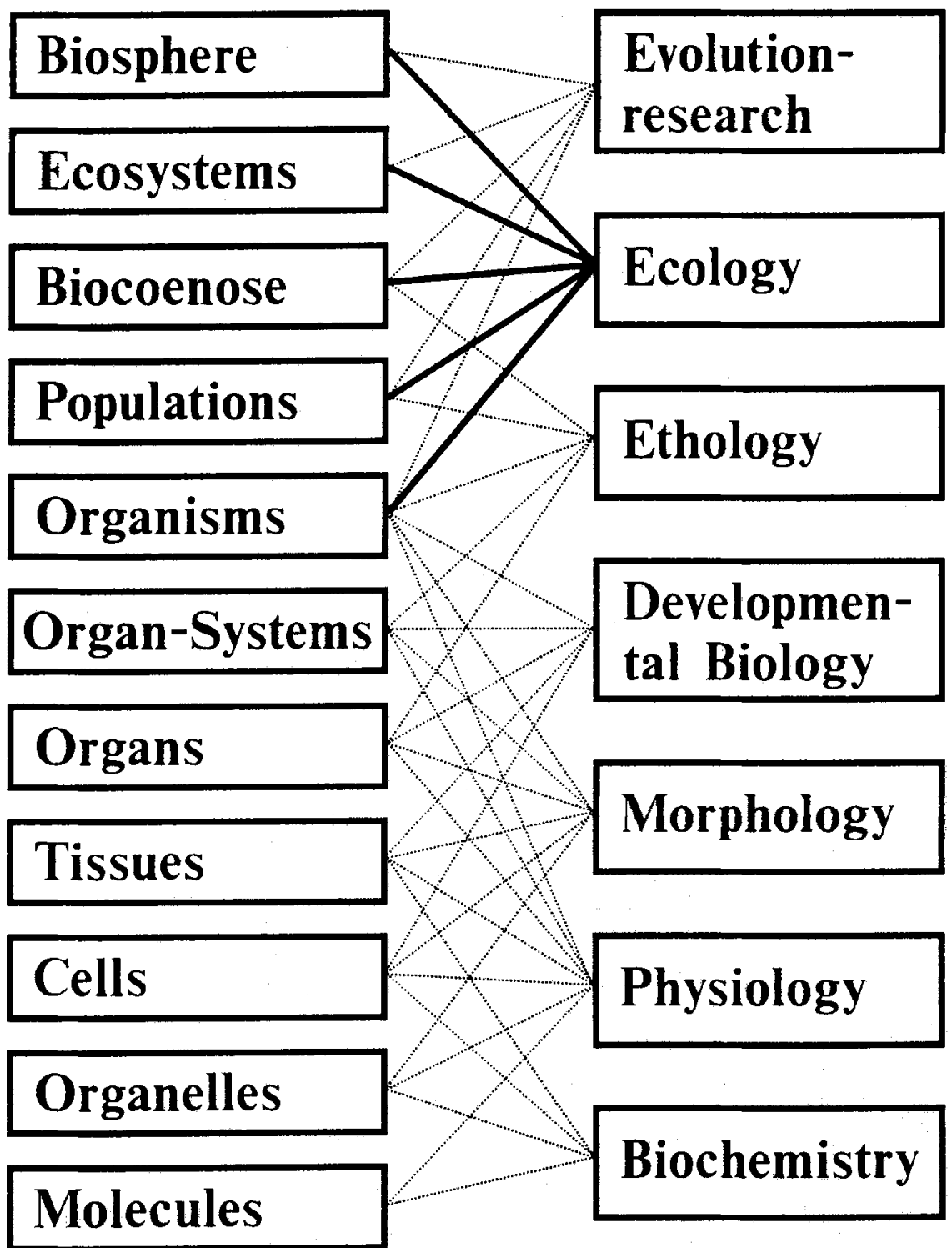

Fig. 2. Disciplines, contributing to the definition of the ecological niche

also had to evaluate the goodness of such prognostic statements, and it seems wise to orient in a science having a comparable system, in order to utilize similar techniques. Livezey (1987) compared the prognostic successes of meteorologists; he uses the term 'skill' for the measurement of the quality of prognoses (Fig. 3). It seems self-evident to treat ecological predictions accordingly.

The most simple prognosis is persistence. The weather/population tomorrow will be the same as today. This prognosis probably has a high skill. But in meteorology the skill of 


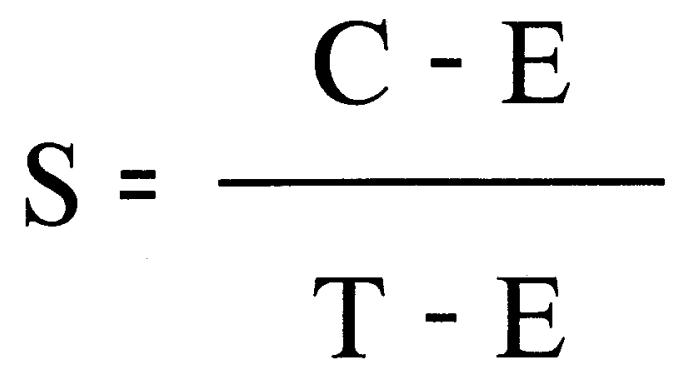

\section{$\mathrm{S}=$ skill score \\ $\mathrm{C}=$ number of correct forecasts (hits) $\mathrm{E}=$ expected number of hits $\mathrm{T}=$ total number of forecasts}

Fig. 3. The meteorological-skill equation (Livezey, 1987)

information-based forecast models is much better for the next day, or days, or even week. It worsens in the case of longer periods. As growth processes depend on solar radiation, some of us may think that ecological processes have the same prognostic scales. But, of course, this mainly concerns a part of the ecosystem and we have buffers built in, called stability (Orians, 1975), resilience (Holling, 1978) or hysteresis. These modify the effect of weather changes and respond more to climatic effects. Successful life-cycle strategies are based on the possible, with which they can deal. Weather changes, currents, river runoff have a natural variance; organisms got aquainted with, or even developed strategies for how to utilize this variability (Wehrtmann \& Stagg, 1990).

\section{OUTLOOK}

Looking at different parts of marine ecology (Fig. 4) the historical development is surprisingly parallel. Population biology was primarily used in fisheries management, starting with Heincke and ending with the most widely accepted prognostic tool, the multispecies virtual population analysis, MSVPA, based on the trophic interaction of fish species (Daan, 1987).

In biocoenotic research, Moebius and to a greater extent Hagmeier (1925), defined the rules. After a period of monofactorial investigations we are now facing new or reinvented theory by Holling (1986), Remmert (1991) and Haken (1977), as a generalist, including ecological processes into general synergetics (Dress et al., 1986; Roth, 1986).

Analytical ecology - coming from Liebig's basic functional relationship, the law of 
Population Prognosis

\begin{tabular}{|c|c|c|c|}
\hline \multicolumn{4}{|c|}{ Prognostic Support Software } \\
\hline $\begin{array}{l}\text { Plankton } \\
\text { Research }\end{array}$ & Population & Functional & Biocoenotic \\
\hline Hensen & Heincke & Liebig & Moebius \\
\hline \multirow{3}{*}{$\begin{array}{c}\text { Strickland } \\
\text { Platt \& } \\
\text { Denman }\end{array}$} & Ricker & Lotka & Hagmeier \\
\hline & Beverton \& & Voltera & von Bertanlanffy \\
\hline & Holt & Ivlev & Haken \\
\hline \multirow{5}{*}{$\begin{array}{l}\text { Banse } \\
\text { Sommer }\end{array}$} & Andersen \& & Holling 65 & Holling 86 \\
\hline & Ursin & Steele & Remmert \\
\hline & $\begin{array}{c}\text { Sinclair } \\
\text { Daan }\end{array}$ & Platt et al. & \\
\hline & & Peters & \\
\hline & & Wulff et al. & \\
\hline
\end{tabular}

Fig. 4. The conceptual basis to marine population prognoses exemplified by publications indicating parallel ways leading to biocoenotic research strategies (for citations, see text)

the minimum - has defined and analyzed prey-predator relationships (Lotka, 1925; Volterra, 1926), the feeding responses of Ivlev (1944) and Holling (1965), stability theory (Orians, 1975) and many elaborate models (e.g. Platt et al., 1981; Franz et al., 1991) until the network theory (Wulff et al., 1989) led analysis straight back to biocoenotic structures.

Plankton research, primarily a global-production biology with strong awareness of the abiotic driving variables, has developed via the "food chain" productivity (Strickland, 1965) into approaches which are named by limnetic planktologists (Sommer, 1989) as 'plankton ecology' and also centre around biocoenotic successions. Succession - the topic of biocoenotic process analysis, the generality and specificity determining population interaction - will be a most important subject in this respect.

MSVPA (Daan, 1987) measures trophic specialization by relating stomach contents to the available food composition in fish. This method is not generally possible. Other approaches, including experimental ones, such as the ARE-value (Greve, 1977) might be a more general approach. On this basis, a system of equations is suggested which replaces a multitude of conceptional aggregations by a generalized expression that stands for any population and its ecological niche (Fig. 5). These equations provide a useful mathematical tool for flexible handling of population interaction on a parameter level without changing the mathematical model (Bente, pers. comm.). This universal niche-model enables us to maintain the specificity of the ecological niche of any developmental stage of any population.

Tools like this will be part of future population prognoses utilizing simulation models equally as empirical and current information. It is not only a case of Peters (1983), 
1. $\mathbf{V}_{\mathrm{R}_{\mathrm{i}}}=\frac{\sum_{\mathrm{j}} \mathrm{PE}_{\mathrm{A}_{\mathrm{j}}} * \mathrm{~A}_{\mathrm{j}}}{\Sigma \mathrm{PE}_{\mathrm{A}_{\mathrm{j}}} * \mathrm{~A}_{\mathrm{j}}+\operatorname{PEMAX}_{\mathrm{R}_{\mathrm{i}}}}$

2. $\mathbf{W}_{\mathbf{R}_{\mathrm{i}}}=\frac{1}{V \mathbf{W} \mathbf{T}_{\mathbf{R}_{(\mathrm{i}-1)}}} * \mathbf{V}_{\mathbf{R}_{(\mathrm{i}-1)}} * \mathbf{R}_{(\mathrm{i}-1)}$

3. $\mathbf{R E}_{\mathbf{R}_{0}}=\sum_{\mathbf{i}} \mathbf{R R}_{\mathbf{R}_{\mathrm{i}}} * \mathbf{V}_{\mathbf{R}_{\mathrm{i}}} * \mathbf{R}_{\mathrm{i}}$

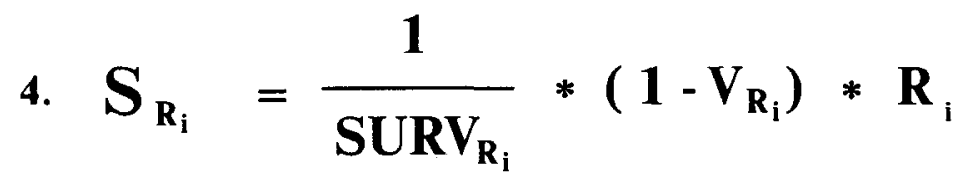

$$
\text { 5. } \mathbf{R}_{\mathrm{i}}=\mathbf{R}_{\mathrm{i}}-\mathbf{R}_{\mathrm{i}} * \Sigma \mathbf{E N}_{\mathrm{A}_{\mathrm{j}}}+\mathbf{W}_{\mathbf{R}_{(\mathrm{i}-1)}}+\mathbf{R E}_{\mathbf{R}_{\mathbf{0}}}-\mathbf{S}_{\mathbf{R}_{\mathrm{i}}}-\mathbf{W}_{\mathbf{R}_{\mathrm{i}}}
$$

Fig. 5. A general definition of an ecological niche, functional relationships after Greve, 1977 (text contains further definitions), discriminating specific populations on the basis of parameter values, only. A: agent, R: reagent, V: metabolic velocity, PE: positive effects, EN: negative effects, PEMAX: Max. nutrient uptake, W: growth, VWT: stage specific minimal residual time, RE: reproduction, RR: max. no. of eggs per stage, S: mortality, SURV: survival (max. starvation tolerance)

demanding predictive ecology: so did Wissel (1981); and Cargo \& King (1990) came out with a forecast model for scyphomedusae. Others are also working on it.

Marine ecology, on the verge of the 21st century, is facing a 'scientific revolution' (Kuhn, 1967). The conditions are given: 


\section{Population Prognoses}

\section{Aggregation of Expertise}

e.g.

Ecophysiology

Population responses

Time series

Regional biocoenotics actual data

- climate

- oceanography

- remote sensing

- continuous plankton recorder

- ICES - young fish survey

- other

\author{
Calculation of \\ Alternatives
}

Statistics

Neural Networks

\section{Simulations}

\section{Test and Definition of Skill-Scores}

to be

developed

Fig. 6. Steps of marine population prognoses

- a crisis of discontent with the social relevance of our results (Peters, 1983);

- the anticipation of changes demanding new and better administrative advice;

- and the aging, paradigmatic leaders, still requesting analytic reductionism.

Population prognoses will face considerable difficulties within the traditional including editorial - paradigms. Testable prognoses must be generally available for testing and evaluation (Fig. 6).

Acknowledgements. I thank Professor von Storch, MPI for Meteorologie, Hamburg, for his introduction into meteorological skill evaluation, and an unknown referee for valuable help.

\section{LITERATURE CITED}

Andersen, K. P. \& Ursin, E, 1977. A multispecies extension to the Beverton and Holt theory of fishing, with accounts of phosphorus circulation and primary production. - Meddr Danm. Fisk. og Havunders. 7, 319-435.

Banse, K. 1976. Rates of growth, respiration and photosynthesis of unicellular algae as related to cell-size - a review. - J. Phycol 12, 135-140. 
Bertanlanffy, L., von, 1950. An outline of general system theory. - Br. J. Phil. Sci 1, 139-164.

Beverton, R. J. H. \& Holt, S. J., 1962. On the dynamics of exploited fish populations. H. M. Stationery Office, London, $533 \mathrm{pp}$.

Cargo, D. G. \& King, D. R., 1990. Forecasting the abundance of the Sea Nettle, Chrysaora quinquecirrha, in the Chesapeake Bay. - Estuaries 13,486-491.

Daan, N., 1987. Multispecies versus single species assessment of North Sea fish stocks. - Can. J. Fish. aquat. Sci. 44 S2; 360-370.

Dress, A., Hendrichs, A. \& Küppers, G. (Hrsg.), 1986. Selbstorganisation. Piper, München, 228 pp.

Elton, C., 1927. Animal ecology. Methuen, London, $207 \mathrm{pp}$.

Fedra, K., 1981. Pelagic foodweb analysis: hypothesis testing by simulation. - Kieler Meeresforsch. (Sonderh.) 5, 240-258.

Fedra, K., 1995. Marine systems analysis and modeling. - Helgoländer Meeresunters. 49, 617-632.

Fransz, H. G., Mommaerts, J. P. \& Radach, G., 1991. Ecological modelling of the North Sea. - Neth. J. Sea Res. 28, 67-140.

Gillbricht, M., 1969. Calculations in marine planktology. - Int. Revue ges. Hydrobiol. 54, 645-660.

Greve, W., 1977. Interspecific interaction: the analysis of complex structures in carnivorous zooplankton populations. - Helgoländer wiss. Meeresunters. 30, 83-91.

Greve, W., 1981. Invertebrate predator control in a coastal marine ecosystem: the significance of Beroe gracilis (Ctenophora). - Kieler Meeresforsch. (Sonderh.) 5, 211-217.

Greve, W. \& Reiners, F., 1991. Systemökologie II: Räumlich-zeitliche Biozönosenentwicklung im Pelagial. Jber. Biol. Anst. Helgoland 1990, 51-54.

Hagmeier, A., 1925. Vorläufiger Bericht über die vorbereitenden Untersuchungen der Bodenfauna der Deutschen Bucht mit dem Petersen Bodengreifer. - Ber. dt. Kommn Meeresforsch. 1, $242-272$.

Haken, H., 1977. Synergetics. Springer, Berlin, $355 \mathrm{pp}$.

Hedgpeth, M. J., 1977 . Models and muddles. - Helgoländer wiss. Meeresunters. 30, 92-104.

Heincke, F., 1878. Die Varietäten des Herings I. - Ber. Kommn Unters. dt. Meere 3, $37-132$.

Holling, C. S., 1965. The functional response of predators to prey density and its role in mimicry and population regulation. - Mem. entomol. Soc. Can. 45, 1-60.

Holling, C. S. (Ed.), 1978. Adaptive environmental assessment and management. Wiley, Chichester, $377 \mathrm{pp}$.

Holling, C. S., 1986. The resilience of terrestrial ecosystems: local surprise and global change. In: Sustainable development of the biosphere. Ed. by W. C. Clark \& R. E. Munn. Cambridge Univ. Press, 292-316.

Huntley, M. E. \& Lopez, M. D. G., 1992. Temperature dependent production of marine copepods: a global synthesis. - Am. Nat. 140, 201-242.

Hurlbert, S. H., 1981. A gentle depilation of the niche: Dicean resource sets in resource hyperspace. - Evol. Theory 5, 177-184.

Ivlev, V. S., 1944. The time for hunting and the path followed by the predator in relation to the density of the prey population. - Zool. Zh. 23, 132-145.

Koudstaal, R., 1987. Water quality management plan North Sea: framework for analysis. Balkema, Rotterdam, $132 \mathrm{pp}$.

Kuhn, T. S., 1967. Die Struktur wissenschaftlicher Revolutionen. Suhrkamp, Frankfurt, 239 pp.

Liebig, J. von, 1840. Chemistry in its application to agriculture and physiology. Taylor \& Walton.

Livezey, R. E., 1987. Caveat emptor! The evaluation of skill in climate predictions. In: Toward understanding climate change. Ed. by U. Radock. Westview Press, London, $199 \mathrm{pp}$.

Lotka, A. J., 1925. Elements of physical biology. Williams \& Wilkins, Baltimore, 460 pp.

Möbius, K., 1877. Die Auster und die Austernwirtschaft. Wiegundt, Hempel and Parey, Berlin, 126 pp.

Orians, G. H., 1975. Diversity, stability and maturity in natural ecosystems. In: Unifying concepts in ecology. Ed. by W. H. v. Dobben \& R. H. Lowe-McConnel. Jung, The Hague, 139-150.

Peters, R. H., 1983. The ecological implications of body size. Cambridge Univ. Press, Cambridge, $329 \mathrm{pp}$.

Platt, T. \& Denman, Ka, 1977. Organisation in the pelagic ecosystem. - Helgoländer wiss. Meeresunters. $30,575-581$.

Platt, T., Mann, K. H. \& Ulanowicz, R. E., 1981. Mathematical models in biological oceanography. The Unesco Press, Paris, 155 pp. 
Remmert, H. (Ed.), 1991. The mosaic cycle concept of ecosystems. Springer, Berlin, 168 pp.

Ricker, W. E., 1957. Stock and recruitment. - J. Fish. Res. Bd Can. 11, 559-623.

Roth, G., 1986. Selbstorganisation - Selbsterhaltung - Selbstreferentialität: Prinzipien der Organisation der Lebewesen und ihre Folge für die Beziehung zwischen Organismus und Umwelt. In: Selbstorganisation. Ed. by A. Dress, H. Hendrichs \& G. Küppers. Piper, München, 149-180.

Sinclair, M., 1987. Marine populations. Univ, of Washington Press, Seattle, 252 pp.

Sommer, U. (Ed.), 1989. Plankton ecology, succession in plankton communities. Springer, Berlin, 369 pp.

Steele, J. S., 1974. The structure of marine ecosystems. Harvard Univ. Press, Cambridge, 128 pp.

Strickland, J. D. H., 1965. Production of organic matter in the primary stages of the marine food chain. In: Chemical oceanography. Ed. by J. P. Riley \& G. Skirrow. Acad. Press, London 1, 477-610.

Valiella, I, 1984. Marine ecological processes. Springer, Heidelberg, $546 \mathrm{pp}$.

Volterra, V., 1926. Fluctuations in the abundance of a species considered mathematically. - Nature, Lond. 188, 558-560.

Wehrtmann, I. \& Stagg, C., 1990. Distribution of Crangon septemspinosa larvae off Chesapeake Bay, USA. - C.M./ICES K7, 1-10.

Wissel, C., 1981. Lassen sich ökologische Instabilitäten vorhersagen? - Verh. Ges. Ökol. 9, $143-152$.

Wulff, F., Field, J. G. \& Mann, K. H., 1989. Network analysis in marine ecology. Springer, Berlin, $284 \mathrm{pp}$. 